\title{
Pengaruh Teknik Relaksasi Benson Terhadap Penurunan Nyeri Pada Pasien Post Operasi Sectio Caesarea di RSUD Dr. Achmad Mochtar Bukittinggi
}

\author{
Kriscillia Molly Morita, ${ }^{1, *}$ Rini Amelia ${ }^{2}$, Diana Putri ${ }^{3}$ \\ ${ }^{1}$ STIKes Yarsi Sumatera Barat Bukittinggi, 26136 Indonesia \\ ${ }^{2}$ STIKes Yarsi Sumatera Barat Bukittinggi, 26136 Indonesia \\ ${ }^{3}$ STIKes Yarsi Sumatera Barat Bukittinggi, 26136 Indonesia \\ ${ }^{1}$ Email : kriscillia1981@ gmail.com*; ${ }^{2}$ Email : riniamelia26@ gmail.com, ${ }^{3}$ Email : dianaputri05@yahoo.com \\ *corresponding author
}

\section{ARTICLE INFO}

\section{Keywords}

Caesarea section

Pain

Benson Relaxation

\section{ABSTRACT}

Cesarean delivery is increasingly in demand by pregnant women in developed and developing countries, this is because advances in science and technology are constantly developing, especially in the field of health. Physiologically, cesarean section surgery can have a postoperative effect that is pain. Pain management in postoperative cesarean section consists of pharmacological and non-pharmacological management. One technique that can be used to reduce pain scale in a non-pharmacological way is Benson's relaxation. The purpose of this study was to determine the effect of Benson's Relaxation Techniques on Pain Reduction in Post Sectio Caesarea Patients in Dr. Achmad Mochtar Bukittinggi in 2019. This study uses Quasi Experimental with the control group. The population in this study were all post-sectio caesarea patients in the Midwifery Room of RSUD Dr. Achmad Mochtar Bukittinggi. The sample of this study was 15 intervention groups and 15 control groups taken with the Non Probality Consecutive sampling technique. Performed in April - Juli 2020. The instrument in this study uses the Numeric Rating Scale (NRS). From the 20 respondents obtained the Independent Sample T-Test parametric test results $\mathrm{p}$ value $0.001(\mathrm{p}<0.005)$. This means that there is an effect of Benson's Relaxation Technique on Pain Reduction in Post Sectio Caesarea Patients at RSUD Dr. Achmad Mochtar Bukittinggi in 2020. With the knowledge of the Effect of Benson Relaxation is expected to be a nursing intervention in reducing pain in post cesarean sectio patients.

\section{Pendahuluan}

Persalinan adalah suatu proses mendorong keluar hasil konsepsi (janin, plasenta dan ketuban) dari dalam rahim lewat jalan lahir atau dengan jalan lain [1]. Persalinan dapat dilakukan dengan dua cara yaitu pervaginam dan pelahiran sectio caesarea (SC). Sebenarnya, persalinan yang dilakukan dengan pervaginam lebih aman jika dibandingkan dengan SC. Efek samping dari obat-obatan yang diberikan saat operasi SC lebih berbahaya dari pada pervaginam. Masa penyembuhan luka juga lebih lama jika dibandingkan persalinan pervaginam, serta pada persalinan SC dapat menimbulkan masalah yang kompleks bagi ibu hamil baik secara fisik, psikologis, sosial, dan spiritual [2].

Persalinan melalui SC (persalinan buatan) dimana janin dilahirkan/dikeluarkan melalui insisi (sayatan) dinding abdomen dan dinding rahim dengan syarat rahim dalam keadaan utuh dan berat janin di atas 500 gram [3]. Operasi SC saat ini menjadi trend dan banyak menjadi pilihan bagi ibu hamil di negara maju disebabkan karena kemajuan ilmu pengetahuan dan teknologi yang terus berkembang terutama dalam bidang kesehatan. Angka kejadian (insidensi) SC mengalami peningkatan hampir di seluruh dunia [2]. 
Tingginya kejadian SC tidak terlepas dari faktor-faktor yang memengaruhinya. Peningkatan kejadian SC tidak hanya terjadi di negara-negara maju saja, negara berkembang juga terjadi peningkatan yang signifikan. Indikasi medis dari SC yaitu placenta prevaria, preeklamsia, gawat janin, kelainan letak janin dan janin besar [4]. Selain karena indikasi medis, SC juga diminati pada ibu saat ini dikarenakan ibu takut menjalani persalinan normal, proses persalinan yang cepat dan juga melalui SC, ibu dapat memilih tanggal ataupun hari baik bagi kelahiran bayinya.

Menurut World Health Organization (WHO) sejak tahun 1985, komunitas kesehatan internasional telah mempertimbangkan tingkat ideal untuk operasi SC menjadi antara 10\% dan 15\% per 1000 kelahiran di dunia. Di tahun 2012, sebanyak 16\% kejadian SC melebihi batas yang direkomendasikan. Survei Global Kesehatan oleh WHO (2013) yang ada didalam data statistik kesehatan dunia menyebutkan bahwa angka kejadian SC terbesar terdapat pada wilayah Amerika (36\%), wilayah Western Pasifik (24\%) dan wilayah Eropa (23\%).

Sejalan dengan penelitian yang dilakukan oleh Osterman et al mengenai perubahan jumlah rata-rata kelahiran melalui SC di Amerika Serikat sejak tahun 1996 (19,7\%) menjadi 32,2\% pada tahun 2011. Data statistik WHO (2013) juga menyebutkan bahwa negara tertinggi dengan kejadian sectio caesarea berada di negara Brazil (52\%),Cyprus (51\%), dan Mexico (39\%). Provinsi tertinggi dengan persalinan melalui SC adalah DKI Jakarta $(27,2 \%)$, Kepulauan Riau (24,7\%), dan Sumatera Barat $(23,1 \%)$ [5].

Menurut data Riskesdas tahun 2013, tingkat persalinan SC di Indonesia (10\%) dari jumlah persalinan, dengan proporsi di Sumatera Barat (14\%) dimana angka tersebut hampir mendekati batas maksimal standar WHO [6]. Berdasarkan data Rekam Medis dari RSUD Dr. Achmad Mochtar Bukittinggi pada bulan Januari sampai dengan Desember 2018 jumlah ibu yang melakukan SC melalui jalur rujukan dari rumah sakit lain, bidan, puskesmas serta faskes lainnya berjumlah 94 orang, meninggal 1 orang dan melalui jalur non rujukan sebanyak 375 orang.

Sayatan pada dinding perut dan uterus untuk melahirkan bayi dan placenta akan menimbulkan rasa nyeri (nyeri superfisial) akibat terputusnya serabut syaraf dan juga tekanan akibat jahitan [7]. Tindakan operasi SC juga mengakibatkan terjadinya perubahan kontinuitas jaringan karena adanya pembedahan. Post SC akan menimbulkan nyeri hebat dan proses pemulihannya berlangsung lebih lama dibandingkan dengan persalinan normal [8].

Nyeri merupakan pengalaman sensori yang dibawa oleh stimulus akibat kerusakan jaringan. Nyeri persalinan merupakan sensasi yang tidak menyenangkan akibat stimulasi saraf sensorik. Nyeri terdiri dari dua komponen, yaitu komponen fisiologis yang merupakan proses penerimaan impuls menuju saraf pusat dan komponen psikologis meliputi rekognisi sensasi, interpretasi rasa nyeri dan reaksi terhadap hasil interpretasi nyeri tersebut [9].

Setelah operasi SC, ibu akan merasakan nyeri dan memberikan dampak yang mengakibatkan mobilisasi ibu menjadi terbatas, Activity of Daily Living (ADL) terganggu, bonding attachment (ikatan kasih sayang) dan Inisiasi Menyusui Dini (IMD) tidak terpenuhi karena adanya peningkatan intensitas nyeri apabila ibu bergerak. Hal tersebut mengakibatkan respon ibu terhadap bayi kurang, sehingga ASI sebagai makanan terbaik bagi bayi dan mempunyai banyak manfaat bagi bayi maupun ibunya tidak dapat diberikan secara optimal [10].

Rasa nyeri dapat diatasi dengan penatalaksanaan nyeri yang bertujuan untuk meringankan atau mengurangi rasa nyeri yang dirasakan klien sampai menuju tingkat kenyamanan. Ada dua cara penatalaksanaan nyeri yaitu farmakologis dan non-farmakologis [11]. Ada beberapa teknik non farmakologis untuk meringankan atau mengurangi rasa nyeri seperti menggunakan sentuhan afektif, sentuhan terapeutik, akupresur, relaksasi dan tehnik imajinasi, istraksi, hipnosis, kompres dingin atau kompres hangat, stimulasi/message kutaneus, TENS (transcutaneous electrical nervestimulation) dan Relaksasi Benson [12].

Pengendalian nyeri secara farmakologi sangat efektif untuk mengatasi rasa nyeri, tetapi pemberian farmakologi tidak bertujuan untuk meningkatkan kemampuan klien sendiri untuk mengontrol nyerinya dan memiliki efek jangka panjang seperti gangguan pada ginjal. Sehingga dibutuhkan kombinasi farmakologi dan non farmakologi agar sensasi nyeri dapat berkurang serta masa pemulihan tidak memanjang. Metode non farmakologi tersebut bukan merupakan pengganti untuk obat-obatan, tindakan tersebut diperlukan untuk mempersingkat episode nyeri yang berlangsung hanya beberapa detik atau menit [13].

Relaksasi nafas dalam merupakan suatu bentuk asuhan keperawatan, yang mengajarkan kepada klien bagaimana cara melakukan napas dalam, napas lambat (menahan inspirasi secara maksimal) dan bagaimana 
menghembuskan napas secara perlahan. Selain dapat menurunkan intensitas nyeri, teknik relaksasi napas dalam juga dapat meningkatkan ventilasi paru dan meningkatkan oksigenasi darah [14].

Relaksasi Benson merupakan pengembangan dari metode relaksasi nafas dalam dengan melibatkan faktor keyakinan pasien yang dapat menciptakan suatu lingkungan yang tenang sehingga dapat membantu pasien mencapai kondisi kesehatan dan kesejahteraan lebih tinggi. Relaksasi benson bekerja dengan cara mengalihkan fokus seseorang terhadap nyeri dan dengan menciptakan suasana nyaman serta tubuh yang rileks maka tubuh akan meningkatkan proses analgesia endogen hal ini diperkuat dengan adanya kalimat atau mantra yang memiliki efek menenangkan [3]. Kelebihan dari teknik relaksasi benson yaitu lebih mudah dilakukan oleh klien dan dapat menekan biaya pengobatan [15].

Relaksasi Benson dapat mengurangi tingkat stress, kecemasan, rasa tidak nyaman, dan juga dapat menurunkan metabolisme, kontraksi jantung, tekanan darah, serta melepas hormon yang berpengaruh terhadap penurunan intensitas nyeri. Nyeri pasca operasi biasanya diikuti dengan cemas, takut, dan depresi. Reaksi emosional ini akan meningkatkan respon simpatik yaitu meningkatnya kadar katekolamin, noradrenalin, dan norepinefrin yang akan mempeparah intensitas nyeri [16].

Relaksasi benson ini sudah dilakukan di beberapa penelitian. Menurut penelitian yang dilakukan Irwan Batubara., dkk (2016) [7] yang berjudul "efektifitas relaksasi Benson terhadap penurunan intensitas nyeri luka post SC di Ruang Bersalin RSUD Kota Padangsidimpuan". Penelitian ini diberikan kepada 48 orang ibu post SC di Ruang Bersalin DiRSUD Kota Padang Sidimpuan dengan menggunakan analisis statistik menggunakan uji t-test berpasangan, diperoleh nilai $\mathrm{P}$ value sebesar 0,000 yang lebih kecil dari $\alpha$ penelitian $(0,05)$, yang berarti relaksasi benson efektif menurunkan nyeri post SC karena efek relaksasi benson mampu menghasilkan hormon endorphin yang memilki fungsi sebagai penghilang rasa sakit.

Berdasarkan dari uraian diatas, maka penulis termotivasi untuk melakukan penelitian tentang pengaruh teknik relaksasi benson terhadap penurunan nyeri pada pasien post sectio caesarea di RSUD Dr. Achmad Mochtar Bukittinggi tahun 2019. Relaksasi telah dikenal dalam meringankan rasa nyeri dan tingkat kecemasan seseorang.

\section{Metode}

Metode yang digunakan dalam penelitian ini Quasi Eksperimental Research bertujuan untuk mengungkapkan hubungan sebab akibat dengan cara melibatkan kelompok kontrol disamping kelompok eksperimen, namun pemilahan kedua kelompok tersebut tidak dengan teknik random [17]. Penelitian ini telah dilakukan di Ruang Kebidanan RSUD Dr. Achmad Mochtar Bukittinggi.Waktu penelitian ini dilakukan pada bulan Mei-Juli.

Populasi dalam penelitian ini adalah pasien post sectio caesarea di RSUD Dr. Achmad Mochtar Bukittinggi pada tahun 2018 sebanyak 469 orang. Sampel dalam penelitian ini 30 orang terdiri dari 15 kelompok intervensi dan 15 kelompok kontrol. Metode sampling yang digunakan adalah Non Probality Consecutive sampling adalah pemilihan sampel yang dilakukan dengan memilih semua individu yang ditemui dan memenuhi kriteria pemilihan, sampai jumlah sampel yang diinginkan terpenuhi.

Cara pengumpulan data yang dilakukan dengan mewawancarai responden untuk mengatahui tingkat nyeri responden sebelum diberikan perlakuan. Setelah data terkumpul lengkap, kemudian responden diajarkan teknik relaksasi benson dan mendemonstrasikan latihan relaksasi benson selama 10-15 menit. Relaksasi ini dilakukan 3 kali setiap 2 jam. Setelah itu diobservasi dan dinilai skala nyeri responden.

Analisa data penelitian ini menggunakan uji $\mathrm{T}$ sampel tidak berpasangan (independen) Dengan syarat dimana nilai sig $<0.05$ artinya secara statistik adanya pengaruh.

\section{Hasil Penelitian}

\section{Analisa Univariat}

Rata - Rata Skala Nyeri Pada Kelompok Intervensi dan Kelompok Kontrol 
Tabel 5.2. Rata-rata Skala Nyeri Pasien Post Sectio Caesarea Pada Kelompok Intervensi dan Kelompok Kontrol di RSUD Dr. Achmad Mochtar Bukittinggi Tahun 2019

\begin{tabular}{lcc}
\hline Kelompok & Mean & SD \\
\hline Intervensi & 1,40 & 0,258 \\
\hline Kontrol & 1,93 & 0,507 \\
\hline
\end{tabular}

Dari tabel 5.2 di atas jelas terlihat rata-rata skala nyeri pada pasien post SC pada kelompok intervensi mean 1,40 dan nilai standar devisiasi 0,258. Sedangkan pada kelompok kontrol nilai mean 1,93 dan nilai standar devisiasi 0.507 .

\section{Analisa Bivariat}

Dari uji normalitas mengggunakan uji Shapiro-Wilk diperoleh nilai sig $>0,05$ maka hal ini dikatakan data berdistribusi normal.

Tabel 5.4. Pengaruh Teknik Relaksasi Benson Terhadap Penurunan Nyeri pada Pasien Post Sectio Caesarea di RSUD Dr. Achmad Mochtar Bukittinggi Tahun 2019

\begin{tabular}{ccccc}
\hline Kelompok & Mean & $\begin{array}{c}\text { Mean } \\
\text { Difference }\end{array}$ & $\mathrm{T}$ & $\mathrm{P}$ value \\
\hline Intervensi & 1,40 & 0,533 & 3,630 & 0,001 \\
\hline Kontrol & 1,93 & 0,933 & \\
\hline
\end{tabular}

Berdasarkan tabel di atas, hasil uji statistik menggunakan uji $t$ independent didapatkan nilai meanskor nyeri pada pasien post SC pada kelompok intervensi 1,40, sedangkan pada kelompok kontrol didapatkan nilai meanskor 1,93. Hasil uji independent $t$-test didapatkan nilai $\mathrm{P}$ value 0,001 . Nilai 0,001 <0,005, dapat disimpulkan bahwa ada pengaruh relaksasi benson terhadap penurunan nyeri pada pasien post SC di RSUD Dr. Achmad Mochtar Bukittinggi.

\section{Pembahasan}

Analisa Univariat

\section{Analisis Rata-rata Skala Nyeri Responden Sebelum Pemberian Relaksasi Benson}

Hasil penelitian pada tabel 5.2 menunjukkan bahwa rata-rata tingkat nyeri responden sebelum pemberian relaksasi benson pada kelompok intervensi didapatkan nilai rata-rata 1,40 sedangkan pada kelompok kontrol didapatkan nilai rata-rata 1,93. Rata-rata nyeri pada kelompok intervensi termasuk kategori nyeri sedang sedangkan rata-rata nyeri pada kelompok kontrol termasuk kategori nyeri berat. Berdasarkan data tersebut,seluruh responden mengalami nyeri.

Hal ini sesuai dengan Woznicki (2004) [17] bahwa nyeri post SC merupakan nyeri sedang dan berat. Hal ini diperkuat oleh penelitian Sloman, Rosen, Rom, dan Shir (2004) yang menemukan bahwa $75 \%$ pasien bedah mengalami nyeri sedang sampai berat setelah operasi. Selain itu hasil penelitian yang dilakukan oleh Bonica (1990) menunjukan bahwa rasa nyeri akibat operasi pada dinding abdomen adalah 10-15\% nyeri berat, 30-50\% nyeri sedang, dan lebih dari 50\% nyeri sedang.

Mansjoer, dkk, (2008) [18] mengatakan bahwa nyeri merupakan suatu mekanisme produksi bagi tubuh, timbul ketika jaringan sedang rusak, dan menyebabkan individu tersebut bereaksi untuk menghilangkan rasa nyeri. Selanjutnya, Judha M, (2012) [19] mengatakan bahwa nyeri adalah pengalaman pribadi, subjektif, yang dipengaruhi oleh budaya, persepsi seseorang, perhatian dan variabel-variabel psikologis lain, yang mengganggu prilaku berkelanjutan dan memotivasi setiap orang untuk menghentikan rasa tersebut.

Prasetyo, (2010) [20] menyatakan bahwa hanya klienlah yang paling mengerti dan memahami tentang nyeri yang ia rasakan. Oleh karena itulah dikatakan klien sebagai expert tentang nyeri yang ia rasakan..Kemampuan mempersepsikan nyeri dipengaruhi oleh beberapa faktor dan 
berbeda diantara individu. Tidak semua orang terpajan terhadap stimulasi yang sama mengalami intensitas nyeri yang sama. Sensasi yang sangat nyeri bagi seorang mungkin hampir tidak terasa bagi orang lain.

Nyeri yang diarasakan responden adalah salah satu stress fisiologis (respon neuroendokrin) yang diakibatkan oleh pembedahan [21]. Nyeri yang dirasakan ibu post partum dengan sectio caesareaberasal dari luka yang terdapat dari perut [22]. Tingkat dan keparahan nyeri pasca operatif tergantung pada fisiologis dan psikologis individu dan toleransi yang ditimbulkan nyeri [23]. Toleransi individu terahadap nyeri merupakan titik yaitu terdapat suatu ketidakinginan untuk menerima nyeri dengan tingkat keparahan yang lebih tinggi dan durasi yang lebih lama. Hal ini diperkuat oleh pendapat bahwa toleransi bergantung pada sikap, motivasi dan nilai yang diyakini seseorang [24].

Pada proses operasi digunakan anestesi agar pasien tidak nyeri pada saat dibedah. Namun setelah operasi selesai dan pasien mulai sadar akan merasakan nyeri di daerah sayatan yang membuat sangat terganggu [25]. Banyak ibu yang mengeluhkan rasa nyeri dibekas jahitan, keluhan ini sebetulnya wajar karena tubuh tengah mengalami luka tersebut tergolong panjang dan dalam. Rasa nyeri di daerah sayatan yang membuat sangat terganggu dan pasien merasa tidak nyaman.

Berdasarkan hasil penelitian yang telah dilakukan,rentang usia responden 25-33 tahun dimana rentang usia ini termasuk dalam rentang usia subur. Menurut [26]), salah satu faktor yang mempengaruhi respon nyeri adalah usia, usia merupakan variable yang penting yang mempengaruhi nyeri. Perbedaan perkembangan yang ditemukan diantara kedua kelompok usia dapat mempengaruhi cara bereaksi terhadap nyeri. Pada penelitian ini tidak ditemukan adanya hubungan pekerjaan terhadap intensitas nyeri. Hal ini sejalan dengan penelitian Anggorowati (2006) [27] pada klien SC dimana ditemukan bahwa tidak adanya hubungan pekerjaan terhadap intensitas nyeri.

Seperti yang dijelaskan [28], mengatakan bahwa reaksi nyeri merupakan respon yang sangat individual, reaksi ini tergantung pada keperibadian, kondisi emosional, tingkat pemahaman pasien, latar belakang kultural, keluarga dan tingkat pendididikan. Pendapat ini diperkuat oleh Nursalam (2001)[29] yang menyatakan bahwa semakin tinggi tingkat pendidikan sesesorang makin mudah menerima informasi, sehingga banyak pula pengetahuan yang dimiliki, sebaliknya pendidikan yang rendah akan menghambat perkembangan sikap seseorang terhadap nilai-nilai yang diperkenalan.

Dengan memahami nyeri yang dialaminya tersebut, tentunya seseorang akan membentuk prilaku-prilaku yang bertujuan untuk membantu meredakan nyeri yang sedang dialami seperti memanfaatkan fasilitas kesehatan tentunya atau pun mencari informasi yang berkaitan dengan terapi-terapi atau pengobatan dalam mengatasi nyeri post sectio caesarea [5].

Berdasarkan hasil temuan penelitian, pada umumnya ibu post SC merasakan nyeri pada skala berat dan skala sedang, hal ini terjadi akibat sayatan yang ada pada perut. Nyeri semakin meningkat karena kerja obat bius yang sebelumnya diberikan untuk menghilangkan rasa sakit mulai menghilang secara bertahap. Ini terjadi sekitar 6 jam pasca pembedahan. Bedasarkan pengamatan peneliti di lapangan, nyeri yang dirasakan setiap ibu berbeda-beda karena nyeri bersifat fisiologis. Respon nyeri yang ditunjukkan ibu post SC seperti susah untuk melakukan mobilisasi dan menyusui anaknya karena ketika ibu bergerak terjadi peningkatan intensitas nyeri. Selain itu,nyeri juga mengganggu aktifitas sehari-hari klien. 


\section{Analisis Rata-rata Skala Nyeri Responden Sesudah Pemberian Relaksasi Benson Pada Kelompok Intervensi}

Hasil penelitian pada tabel 5.3 menunjukkan bahwa rata-rata tingkat nyeri responden sesudah pemberian relaksasi benson pada kelompok intervensi didapatkan nilai rata-rata 3,40 dengan skala nyeri terendah 2 dan skala nyeri tertinggi 5 dan nilai standar devisiasi 1,07. Maka didapatkan selisih nilai rata-rata pretest-posttest pada kelompok intervensi 3,20. Secara garis besar terdapat perubahan nyeri pada responden sesudah pemberian relaksasi benson.

Pada penelitian Nesam, Masoumeh, Bandpei, Mohammad, Azar dan Masoud (2006); Sukowati (2007);[28] Rohman (2007); serta Fadilah (2007) menemukan bahwa teknik relaksasi ini efektif dalam mengurangi nyeri. Hal ini sejalan dengan penelitian Anggorowati (2006) [27] yang menemukan bahwa pemberian intervensi spiritual dapat menurunkan intensitas nyeri klien post SC lebih banyak dibandingkan kelompok yang tidak diberikan intervensi ini.

Menurut Purwanto (2011) [31], tujuan dilakukannya relaksai benson adalah untuk menciptakan suasana intern yang nyaman sehingga mengalirkan fokus terhadap sensasi nyeri pada hipotalamus sehingga dapat menurunkan sensasi nyeri yang dirasakan oleh individu yang bersangkutan. Relaksasi benson dalam hal berperan untuk menurunkan intensitas persepsi nyeri bekerja dengan cara mengalihkan fokus seseorang terhadap nyeri dan dengan menciptakan suasana nyaman serta tubuh yang rileks maka tubuh akan meningkatkan proses analgesia endogen hal ini diperkuat dengan adanya kalimat atau mantra yang memiliki

efek menenangkan atau menggunakan kata-kata yang mampu mempengaruhi korteks serebri karena tehnik relaksasi benson menyatakan unsur religi didalamnya dimana semua umat yang percaya akann "sang pencipta" juga percaya akan "kuasanya" dimana hal ini semakinmemberikan efek relaksasi yang pada akhirnya meningkatkan proses analgesia endogen sehingga mampu menggurangi persepsi nyeri seseorang.

Memindahkan pikiran-pikiran yang berorientasi pada hal-hal yang logis dan yang berada diluar diri harus ada suatu rangsangan yang konstan yaitu satu kata atau frase singkat yang diulang-ulang dalam hati sesuai dengan keyakinan. Kata atau frase yang singkat merupakan fokus dalam melakukan relaksasi benson. Fokus terhadap kata atau frase singkat akan meningkatkan kekuatan dasar respons relaksasi dengan memberi kesempatan faktor keyakinan untuk memberi pengaruh terhadap penurunan aktifitas saraf simpatik [32].

Menurut Benson (2004) [32] formula yang dibaca berulang-ulang dengan melibatkan unsur keimanan kepada agama, kepada tuhan yang disembah akan menimbulkan respon relaksasi yang lebih kuat dibandingkan dengan sekedar relaksasi tanpa melibatkan unsur keyakinan terhadap hal tersebut. Menurut Benson dan Proctor (2000) Benson relaksasi memiliki efek penyembuhan. Dampak intervensi ini tidak terbatas pada penyembuhan tekanan darah tinggi dan penyakit jantung, ataupun kecemasan saja, tetapi sampai pada tingkat mampu menurunkan rasa nyeri.

Relaksasi Benson adalah salah satu cara untuk mengurangi nyeri dengan mengalihkan perhatian kepada relaksasi sehingga kesadaran klien terhadap nyeri-nya berkurang, relaksasi ini dilakukan dengan cara menggabungkan relaksasi yang diberikan dengan kepercayaan yang dimiliki klien. Individu yang mengalami ketegangan dan kecemasan yang bekerja adalah sistem saraf simpatis, sedangkan pada waktu relaksasi yang bekerja adalah sistem saraf parasimpatis, dengan demikian relaksasi dapat menekan rasa tegang, cemas, insomnia, dannyeri [33].

Menurut peneliti, yang menyebabkan terjadi penurunan nyeri di ruang kebidanan RSUD Dr. Achmad Mochtar Bukittinggi setelah melakukan teknik relaksasi benson disebabkan pengalihan fokus nyeri yang membuat individu merasakan nyaman dan rileks dan juga akibat dari penggunaan kalimat "istighfar" yang membuat individu semakin dekat dengan Allah SWT karena mengingat Allah SWT hati menjadi tenang. Hal ini terlihat dari respon dan ekspresi klien yang mengatakan setelah melakukan relaksasi benson merasakan tenang dang rileks.

Pasien post SC yang melakukan relaksasi benson mengalami penurunan tingkat nyeri tetapi tidak menghilangkan nyeri tersebut karena luka dari operasi SC tersebut merupakan luka yang dibuat mulai dari lapisan perut sampai ke lapisan uterus yang penyembuhannya bertahap. Asumsi ini diperkuat oleh beberapa responden menceritakan sebelum peneliti mengajarkan teknik relaksasi benson,responden telah melakukan "istighfar" terlebih dahulu,sehingga memudahkan peneliti untuk memberitahukan cara atau pedoman melakukan Relaksasi Benson sesuai dengan pedoman yang ada. 


\section{Analisis Rata-rata Skala Nyeri Responden Pada Kelompok Kontrol}

Hasil penelitian pada tabel 5.3 menunjukkan bahwa rata-rata tingkat nyeri responden pada kelompok kontrol didapatkan nilai rata-rata 5,40 dengan skala nyeri terendah 3 dan skala nyeri tertinggi 7 dan nilai standar devisiasi 1,26. Maka didapatkan selisih nilai rata-rata pretest-posttest pada kelompok kontrol 1,70. Apabila dibandingkan dengan tingkat nyeri sebelum diberikan relaksasi benson dengan setelah diberikan relaksasi benson pada umumnya responden mengalami penurunan tingkat nyeri pada kelompok intervensi sedangkan pada kelompok kontrol cendrung sedikit responden yang mengalami penurunan tingkat nyeri.

Hasil penelitian ini mendukung hasil penelitian sebelumnya bahwa relaksasi benson efektif untuk mengurangi rasa nyeri pasca bedah. Seperti yang dilakukan oleh Datak (2008) [33] mengenai efektifitas relaksasi benson terhadap nyeri pascabedah pasien TUR prostat juga membuktikan bahwa relaksasi benson efektif mengatasi nyeri dibandingkan hanya menggunakan terapi analgetik saja dengan $\mathrm{p}$ value $0,019<\alpha(0,05)$. Hal ini dikarenakan relaksasi benson menghambat aktifitas saraf simpatik yang megakibatkan penurunan terhadap konsumsi oksigen oleh tubuh dan selanjutnya otot-otot tubuh menjadi rileks sehingga menimbulkan perasaan tenang dan nyaman, selain itu responden pada penelitian adalah lanjut usia sehingga Datak mengasumsikan responden memiliki kematangan spiritual yang baik.

Penelitian yang dilakukan oleh Yuliasna dkk [8] dengan judul "efektivitas relaksasi benson terhadap penurunan nyeri pada ibu postpartum sectio caesarea di RSUD Arifin Achmad" yang menggunakan uji $t$ dependent, didapatkan nilai $\mathrm{p}$ value nyeri 0,000 berarti $\mathrm{p}$ value $<0,05$ maka Ho ditolak, yang berarti bahwa nyeri pada ibu postpartum sectio caesarea dengan menggunakan relaksasi benson lebih efektif untuk menurunkan skor nyeri.

Nyeri yang diarasakan responden adalah salah satu stress fisiologis (respon neuroendokrin) yang diakibatkan oleh pembedahan [34]. Pada kelompok eksperimen yaitu yang diberikan relaksasi benson didapatkan penurunan nyeri lebih besar dibandingkan dengan kelompok kontrol. Hal ini sesuai dengan penelitian yang dilakukan oleh Riska (2013) yang menyatakan bahwa relaksasi benson dapat menurunkan kecemasan pada penderita kanker serviks.

Relaksasi merupakan salah satu metode pengendalian nyeri yang sering digunakan dan memberikan masukan terbesar dalam penurunan nyeri. Hal ini sesuai dengan penelitian yang dilakukan oleh Bagharpoosh dkk (2006) dalam Sulistyowati (2009) menunjukkan bahwa relaksasi sangat efektif untuk mengurangi nyeri, merupakan cara mudah yang dapat dilakukan, tanpa resiko dan hanya memerlukan sedikit biaya.

Menurut peneliti, penurunan intensitas nyeri pada kelompok kontrol, hanya sedikit responden yang mengalami penurunan intensitas nyeri dari pada kelompok intervensi. Karena pada kelompok kontrol hanya mendapatkan terapi farmakologi tanpa non farmakologi. Terapi farmakologi memang berguna untuk menghilangkan nyeri, tapi tidak memberikan rasa nyaman dan tenang pada klien maupun psikologinya.

Pemberian farmakologi juga membuat klien susah untuk mengontrol rasa nyerinya karena klien berpikir bahwa ketika mereka merasakan nyeri kembali ada obat untuk menghilangkan rasa nyeri tersebut. Padahal obat-obatan yang dikonsumsi terus-menerus akan memberikan efek di kemudian hari. Kombinasi antara farmakologi dan non farmakologi sangat efektif dalam penurunan nyeri post SC dari pada hanya memberikan terapi farmakologi saja ataupun memberikan non farmakologi saja.

\section{Analisis Bivariat}

Berdasarkan tabel 5.4 dari 20 responden (10 kelompok intervensi dan 10 kelompok kontrol) menggunakan analisis statistik menggunakan uji t independent, diperoleh nilai $p=0,001$ pada kelompok intervensi maupun kelompok kontrol. Pada peneltian ini didapatkan $\mathrm{p}$ value sebesar 0,001 di mana $<0,05$. Karena $<0,05$ maka terdapat perbedaan bermakna secara statistik atau signifikan pada kelompok intervensi maupun kelompok kontrol. Hal ini menunjukan terdapat pengaruh teknik relaksasi benson terhadap penurunan nyeri pada pasien post $\mathrm{SC}$ karena $\mathrm{p}<0,05$. 
Hal ini sejalan dengan penelitian mengenai relaksasi benson juga diteliti oleh Novitasari \& Aryana (2013) [35]. dengan judul pengaruh teknik relaksasi benson terhadap penurunan tingkat stres lansia di unit rehabilitasi sosial wening wardoyo ungaran. Penelitian ini dilakukan dengan jumlah responden 30 yang hasil penelitian menunjukkan ada pengaruh yang signifikan teknik relaksasi benson terhadap tingkat stres lansia dengan $p$ value $0,002<\alpha(0,05)$.

Ketika relaksasi mengalihkan pikiran, thalamus akan menengahi perhatian secara selektif ke kortek prefrontal untuk merubah suara-suara terhadap rangsangan nyeri sehingga menghambat impuls nyeri. Kemudian otak sebagai penghambat impuls menutup pintu transmisi pada impuls noxius sehingga impuls nyeri tidak dapat dirasakan atau dihambat [32] dan alur serabut saraf desenden melepaskan opioid endogen seperti endorfin dan dimorfin sebagai penghambat nyeri alami yang berasal dari tubuh [24]. Neuromodulator ini menutup mekanisme pertahanan dengan menghambat pelepasan substansi P.

Menurut Penelitian Anita Yusliana, Misrawatin dan Safri (2015) [8] yang berjudul efektivitas relaksasi benson terhadap penurunan nyeri pada ibu postpartum section caesarea. Hasil uji statistika menggunakan uji t independent. Nilai p value $(0,000)<(0,05)$, maka Ho ditolak sehingga dapat disimpulkan bahwa pemberian relaksasi benson efektif terhadap penurunan skor nyeri pada ibu post partumsectio caesarea

Teknik relaksai nafas dalam ini dapat merangsang tubuh menghasilkan endorphin dan enfikelin ini adalah zat kimiawi endogen yang bersetruktur seperti opioid, yang mana endorphin dan enfikelin dapat menghambat imflus nyeri dengan memblok transmisi implus didalam otak dan medulla spinali.

Keuntungan dari relaksasi benson selain mendapatkan manfaat dari relaksasi juga mendapatkan kemanfaatan dari penggunaan keyakinan seperti menambah keimanan, dan kemungkinan akan mendapatkan pengalaman-pengalaman transendensi. Individu yang mengalami ketegangan dan kecemasan yang bekerja adalah sistem saraf simpatis, sedangkan pada waktu relaksasi yang bekerja adalah sistem saraf parasimpatis, dengan demikian relaksasi dapat menekan rasa tegang, cemas, insomnia dan nyeri [33].

Berdasarkan hasil yang diperoleh peneliti dilapangan, pada kelompok responden yang tidak diberikan teknik relaksasi benson terjadi penurunan tingkat nyeri yang lebih sedikit dari kelompok yang diberikan teknik relaksasi benson.. Karena pada kelompok kontrol hanya mendapatkan terapi farmakologi tanpa non farmakologi.

Semakin sering responden melakukan teknik relaksasi benson, maka penurunan nyeri post SC dan ibu yang melakukan relaksasi akan merasa tenang dan nyaman. Hal ini terjadi ketika responden melemaskan semua otot dan mengambil posisi yang nyaman dan mengambil oksigen melalui hidung serta mengucapkan kalimat "istighfar" dan gelombang otak pun menjadi teratur serta aliran darah pun menjadi lancar. Peneliti juga menyatakan ketika individu melakukan relaksasi maka reaksi-rekasi fisiologis yang dirasakan individu akan berkurang.

Teknik mengurangi nyeri dengan Relaksasi Benson ini pada dasarnya merupakan penggabungan antara relaksasi dengan suatu faktor keyakinan filosofis atau agama yang dianut. Relaksasi benson dilakukan 3 kali (sekali 2 jam) selama 10-15 menit. Salah satu kesulitan untuk melaksanakan relaksasi benson adalah pikiran yang megembara, namun dapat dicegah dengan pengulangan kata atau frase.

\section{Kesimpulan}

1. Didapatkan nilai rata-rata skala nyeri responden pada kelompok intervensi sebelum diberikan relaksasi benson adalah 6,60 dan didapatkan nilai rata-rata skala nyeri responden pada kelompok intervensi setelah diberikan relakasai benson adalah 3,40. Terjadi penurunan nilai rata-rata pada kelompok intervensi sebelum dan sesudah diberikan relaksasi benson dengan nilai 2,20 . 
2. Didapatkan nilai rata-rata skala nyeri responden pada kelompok kontrol (pretest) adalah 7,10 dan didapatkan nilai rata-rata skala nyeri responden pada kelompok kontrol yang hanya diberikan terapi farmakologi tanpa non farmakologi (posttest) tadalah 5,40. Terjadi penurunan nilai rata-rata pada kelompok kontrol sebelum dan sesudah dengan nilai 1,70.

3. Terdapat perbedaan penurunan rata-rata skala nyeri responden antara kelompok intervensi dan kelompok kontrol dengan beda rata-rata $-2,000$ dan $p=0,001$.

\section{Saran}

1. Bagi Lahan Penelitian

Diharapkan kepada lahan penelitian penelitian ini dapat memberikan kontribusi dan mengembangkan keperawatan khususnya dalam penanganan nyeri non farmakologis, sebagai bahan untuk mengambil kebijakan mengenai pendekatan psikologis dan spiritual berupa relaksasi benson dalam mengatasi rasa nyeri pada pasien post SC.

2. Bagi Institusi Pendidikan

Diharapkan kepada pihak instansi pendidikan STIKes Yarsi Sumbar Bukittinggi menjadikan penelitian ini menjadi sumber teoritis untuk menangangi nyeri secara non farmakologis.

\section{Bagi Peneliti Selanjutnya}

Diharapkan kepada peneliti selanjutnya untuk dapat melakukan penelitian lebih lanjut tentang teknik non farmakologis yang efektif terhadap penurunan skala nyeri. Hasil penelitian ini bias dijadikan evidence based dan tambahan informasi untuk mengembangkan penelitian lebih lanjut tentang manfaat relaksasi benson terhadap kesehatan dengan jumlah sampel yang lebih banyak atau faktor-faktor yang lainnnya.

\section{Referensi}

[1] Reeder, Sharon J. 2012. Keperawatan Maternitas Kesehatan Wanita, Bayi, dan Keluarga. Jakarta: ECG

[2] Megawahyuni, A., Hasnah, H., \& Azhar, M. U. (2018). Pengaruh Relaksasi Nafas Dalam Dengan Teknik Meniup Balon Terhadap Perubahan Skala Nyeri Pasca Operasi Seksio Sesarea Di Rsia Bahagia Makassar. Jurnal Kesehatan, 11(1), 51-60. https://doi.org/10.24252/kesehatan.v11i1.5028

[3] Wahyu, A. (2018). EFEKTIFITAS RELAKSASI BENSON TERHADAP PENURUNAN NYERI PASIEN PASCA SECTIO CAESAREA. 2(1), 236-251.

[4] Bobak. 2004. Buku Ajar Keperawatan Maternitas. Jakarta: ECG.

[5] Depkes RI. 2011. Target Tujuan Pembangunan MDGs. Direktorat Jendral Kesehatan Ibu dan Anak. Jakarta.

[6] Mulyawati. (2011). Faktor - faktor yang berhubungan dengan tindakan persalinan melalui operasi sectio caesarea di RS YAKKSI Gemolong Kab. Sragen. http ://Journal Unnes. Ac. Id / index. php/ Kemas.

[7] Batubara, I., Indrani Harahap, E., \& Siregar, R. (2016). PENGARUH RELAKSASI BENSON TERHADAP NYERI PADA PASIEN POST SEKSIO SESARIA DI RSUD KOTA PADANGSIDIMPUAN. Jurnal Ilmiah PANMED, 10, 301-3014

[8] Yusliana, A., Misrawati, \& Safri. (2015). Efektivitas relaksasi benson terhadap penurunan nyeri pada ibu postpartumsectio caesarea. 2(2).

[9] Astutik, P., \& Kurlinawati, E. (2018). Pengaruh Relaksasi Genggam Jari Terhadap Penurunan Nyeri Pada Pasien Post Sectio Caesarea. Strada Jurnal Ilmiah Kesehatan, 6(2), 30-37. https://doi.org/10.30994/sjik.v6i2.6 
[10] Haniyah, S., Setyawati, M. B., \& Sholikah, S. M. (2016). Efektifitas Teknik Relaksasi Genggam Jari Terhadap Nyeri Post Sectio Caesarea Di RSUD Ajibarang. 233-239.

[11] Smeltzer, S.C. \& Bare, B.G. (2013). Buku Ajar Keperawatan Medikal Bedah. Brunner \& Suddarth, edisi 8. Jakarta : EGC.

[12] Fithriana, D., Firdiyanti, N., \& Zilfiana, M. (2018). Pengaruh Relaksasi Benson Terhadap Penurunan Nyeri Pada Pasien Post Operasi Sectio Caesarea Di Ruang Nifas Rsud Praya. Prima, 4(2), 14-24.

[13] Nasuha, Widodo, D., \& Widiani, E. (2016). Pengaruh Teknik Relaksasi Nafas Dalam Terhadap Tingkat Kecemasan Pada Lansia Di Posyandu Lansia Rw IV Dusun Dempok Desa Gading Kembar Kecamatan Jabung Kabupaten Malang. 1, 53-62.

[14] Solehati, Tetti dan Cecep Eli Kosasih., 2015. Konsep dan Aplikasi Relaksasi dalam Keperawatan Maternitas. Bandung : PT. Refika Aditama.

[15] Sueb, C. T. (2016). Relaksasi Benson Dapat Menurunkan Nyeri Paska Trans-Urethral Resection of the Prostate (Turp). Keperawatan Soedirman, 11(2), 17-22.

[16] Woznicki,K.(2005).ASA:Easy test predict cesarean post op pain .http://www.medpagetody.com

[17] Mansjoer, A, 2008, Buku Ajar Asuhan Keperawatan Klien Gangguan Sistem Muskuluskeletal, Jakarta: EGC

[18] Afroh F, Judha M, Sudarti. 2012. Teori Pengukuran Nyeri \& Nyeri Persalinan, Nuha Medika: Yogyakarta

[19] Prasetyo, Sigit Nian ( 2010 ). Konsep dan Proses Keperawatan Nyeri. Edisi I Yogyakarta: Graha Ilmu.

[20] Baradero, Dayrit, Siswadi. 2009. Seri Asuhan Keperawatan : Klien Gangguan Ginjal. Jakarta: EGC

[21] Kasdu. (2003). Buku Ajar Medikal Bedah. Jogjakarta : Graha Ilmu.

[22] Brunner dan Suddarth. 2001. Keperawatan Medikal Bedah. Edisi 8 Volume 2. Jakarta : Penerbit Buku Kedokteran EGC.

[23] Potter, Perry. (2010). Fundamental Of Nursing: Consep, Proses and Practice. Edisi 7.

[24] Whaley dan Wong. (2008). Dikutip dari: Ballantyne JC. Management of acute postoperative pain. In: Longnecker DE, Brown DL, Newman MF, Zapol WM, editors. Anesthesiology. New York: McGraw-Hill.

[25] Hestiantoro A. dkk. Masalah Gangguan Haid dan Infertilitas. Jakarta : FKUI; 2008.

[26] Anggorowati, dkk. 2007. Efektifitas Pemberian Intervensi Spiritual "Spirit Ibu" terhadap Nyeri Post Sectio Caesarean (SC) pada RS Sultan Agung dan RS Roemani Semarang. Journal Media Ners Vol 1, No 1, Tahun 2007: 10 - 15.

[27] Farrer, H. (2001). Keperawatan Maternitas. Edisi 4, Vol 2, Alih Bahasa: dr. Andry Hartono. Jakarta: EGC

[28] Nursalam. 2008. Konsep dan penerapan metodologi penelitian keperawatan

[29] Sukowati, U. (2007). Efektifitas paket rileks terhadap rasa nyeri ibu primipara kala I fase aktif di RSUD dr Haryoto Lumajang Jawa Timur. Tidak dipublikasikan.

[30]Purwanto. (2011). Pengaruh Latihan Relaksasi Religius untuk Mengurangi Insomnia di Yogyakarta. Universitas Muhammadiyah Yogyakarta.

[31] Benson dan Proctor. (2011). Dasar-Dasar Respon Relaksasi: Bagaimana Menghubungkan Respon Relaksasi Dengan Keyakinan Pribadi Anda (Ahli Bahasa oleh Nurhasan. Bandung: Kaifah

[32] Datak, G., Yetti, K \& Hariyati, S.T. (2008). Penurunan nyeri pascabedah pasien tur prostat melalui relaksasi benson. Jurnal keperawatan Indonesia, vol 12 no 3, 173- 178. Diperoleh dari http://jki.ui.ac.id

[33] Baradero, Dayrit, Siswadi. (2008). Keperawatan Perioperatif: Prinsip dan Praktik. Jakarta: EGC.

[34] Novitasari, D. \& Aryana, K. O. (2013). Pengaruh Tehnik Relaksasi Benson Terhadap Penurunan Tingkat Stres Lansia di Unit Rehabilitas Sosial Wening Wardoyo Ungaran. 